\title{
Red Devonian trilobites with green eyes from Morocco and the silicification of the trilobite exoskeleton
}

Christian Klug, Hartmut Schulz, and Kenneth De Baets

Acta Palaeontologica Polonica 54 (1), 2009: 117-123 doi:http://dx.doi.org/10.4202/app.2009.0112

Latest Emsian (Early Devonian) sediments at the famous mud-mound- and trilobite-locality Hamar Laghdad (Tafilalt,

Morocco) yielded some red-coloured remains of phacopid trilobites. Closer examination revealed that the eyes of these phacopids are often greenish in colour. EDX-analyses showed that the lenses retained their original calcitic composition, possibly greenish due to Fe-impurities, while most of the exoskeleton was silicified. The silicified parts contain elevated concentrations of iron which causes the red colour. This phenomenon is explained by the porosity of the exoskeleton in contrast to the homogeneous and massive construction of the lenses and their $\mathrm{Mg}$-content. These incompletely silicified trilobites enabled a reconstruction of the silicification process in trilobites. Their diagenetic alteration probably occurred as a result of events associated with the Cretaceous transgression.

Key words: Trilobita, taphonomy, diagenesis, silicification, transgression, mud-mounds, Devonian, Morocco.

Christian Klug [chklug@pim.uzh.ch], Kenneth DeBaets [kenneth.debaets@pim.uzh.ch

], Paläontologisches Institut und Museum der Universität Zürich, Karl

Schmid-Str. 4, CH-8006 Zürich, Switzerland; Hartmut Schulz [hartmut.schulz@uni-tuebingen.de], Institut für Geowissenschaften, Eberhard-Karls-Universität Tübingen, Sigwartstr. 10, D-72076 Tübingen, Germany.

This is an open-access article distributed under the terms of the Creative Commons Attribution License (for details please see creativecommons.org), which permits unrestricted use, distribution, and reproduction in any medium, provided the original author and source are credited. 
Forif Full text $(512.8 \mathrm{kB})$ 